\title{
Effects of increasing amounts of dietary wheat on performance and ruminal fermentation of Holstein cows
}

\author{
L. Doepel, ${ }^{* 1,2}$ A. Cox, ${ }^{*^{3}}$ and A. Hayirlit \\ *Department of Agricultural, Food and Nutritional Science, University of Alberta, Edmonton, AB, Canada T6G 2P5 \\ †Department of Animal Nutrition and Nutritional Disorders, Faculty of Veterinary Medicine, Atatürk University, Erzurum 25700, Turkey
}

\begin{abstract}
Twelve second-lactation Holstein cows were used in a replicated Latin square design to examine the effects of dietary wheat on lactation performance, ruminal fermentation, and whole-tract nutrient digestibility. Cows were randomly assigned to 1 of 3 diets containing 0,10 , and $20 \%$ steam-rolled wheat on a dry matter basis at the expense of steam-rolled barley. Cows were fed and milked twice daily. Six of the cows were ruminally cannulated, and rumen fluid samples were obtained from these cows 18 times during the last $2 \mathrm{~d}$ of each period. Treatment did not affect dry matter intake $(20.9 \mathrm{~kg} / \mathrm{d})$ or yields of milk $(36.1 \mathrm{~kg} / \mathrm{d})$ or milk components $(1.25$, 1.10 , and $1.67 \mathrm{~kg} / \mathrm{d}$ for fat, protein, and lactose, respectively). Fat percentage was not different among the treatments but protein content of the milk was reduced by the wheat treatments, and was lower when $10 \%$ wheat was included in the diet versus $20 \%$. Cows fed wheat had lower ruminal $\mathrm{pH}$ (6.36 vs. 6.44$)$ and greater $\mathrm{NH}_{3}-\mathrm{N}(11.49$ vs. $8.10 \mathrm{mg} / \mathrm{dL})$ and total volatile fatty acids (121 vs. $113 \mathrm{mM}$ ) concentrations than cows not fed wheat. The acetate:propionate ratio was lower for cows fed wheat than for those not fed wheat (3.21 vs. 3.36 ), but was not different between cows fed $10 \%$ versus $20 \%$ wheat. Wheat feeding did not alter whole-tract apparent digestibility of dry matter, crude protein, acid detergent fiber, and neutral detergent fiber. Results of this study show that up to $20 \%$ steam-rolled wheat can be included in the diet of dairy cows without compromising production or causing subacute ruminal acidosis if adequate fiber is provided and the diets are properly formulated and mixed.
\end{abstract}

Key words: wheat, dairy cow, digestibility, fermentation

\footnotetext{
Received January 30, 2008.

Accepted April 26, 2009.

${ }^{1}$ Corresponding author: lorraine.doepel@ualberta.ca

${ }^{2}$ Current address: University of Calgary Faculty of Veterinary

Medicine, 3330 Hospital Drive NW, Calgary, Alberta, Canada.

${ }^{3}$ Current address: Western College of Veterinary Medicine, Saskatoon, SK, Canada.
}

\section{INTRODUCTION}

Barley (Hordeum vulgare L.) is a commonly grown crop throughout western Canada and is extensively fed to dairy cows. Wheat (Triticum aestivum L.) is also a prevalent crop in western Canada but is used primarily for human consumption. Grains are incorporated into dairy cow diets to provide readily fermentable carbohydrates that serve as energy precursors for the rumen microorganisms. The nutritive value of barley for ruminants is different from that of wheat. The NRC (2001) reports the net energy value and concentrations of protein, ADF, and NDF as $1.86 \mathrm{Mcal} / \mathrm{kg}$ and 12.4 , 7.2 , and $20.8 \%$ for rolled barley and $1.99 \mathrm{Mcal} / \mathrm{kg}$ and $14.2,4.4$, and $13.4 \%$ for rolled wheat, respectively. The higher ADF and NDF content of barley compared with wheat is related to its kernel being covered with a greater mass of outer layer that consists of the hull, pericarp, and testa.

The primary carbohydrate in grains is starch. The starch content of wheat is greater than that of barley (77\% vs. 57 to $58 \%$; Huntington, 1997). Ruminal starch degradability varies with grain type and is reported to be in the order (greatest to least) of oats, wheat, barley, and corn (Herrera-Saldana et al., 1990). The rate and extent of starch digestion in the rumen are influenced by several factors, including the source of dietary starch, the rate of feed consumption, adaptation of the rumen microbial population to the diet, and grain processing, either physical (e.g., grinding, rolling) or chemical (e.g., $\mathrm{NaOH}$ treatment) (Huntington, 1997). Processing methods that disrupt the seed coat improve digestibility, and hence the nutritive value, of grains by allowing greater opportunity for attachment of rumen microbes to the starch granules (Huntington, 1997). Improvements in digestibility caused by processing have been documented for both barley and wheat (see review of Huntington, 1997).

In general, dairy producers in Canada are reluctant to feed wheat to dairy cows because of the belief that it will result in subacute ruminal acidosis because of its higher starch content and potentially faster degradation compared with barley, which is commonly fed. However, 
the published literature does not necessarily support this belief. Tománková and Homolka (2004) reported that ruminal starch degradability for barley and wheat differed at $4 \mathrm{~h}$ ( $44 \%$ vs. $59 \%)$ but was the same at 16 h $(83 \%)$ postincubation. Offner et al. (2003) also reported that ruminal degradability of starch from wheat and barley was similar. Similarly, Herrerra-Saldana et al. (1990) demonstrated that the rates of disappearance of starch and protein in ground wheat and barley were not different. Conversely, Turgut et al. (2004) compared in sacco degradability of barley and wheat and found that the difference in disappearance rate of $\mathrm{CP}$ became significant at 8 h (69 vs. $83 \%$ ) and continued until 24 h (87 vs. 94\%), but was not significant at 48 h (98\%). However, because of a substantial difference in ruminal outflow rate, effective degradability of $\mathrm{CP}$ was lower for barley than for wheat (76 vs. $82 \%$ ).

In vivo studies dealing with wheat grain feeding to dairy cows are limited. This study was therefore conducted to determine production, rumen fermentation, and whole-tract nutrient digestibility responses in cows fed diets differing in the amount of wheat.

\section{MATERIALS AND METHODS}

\section{Cows, Diets, and Management}

Twelve second-lactation Holstein cows averaging 98 \pm 15 DIM (mean $\pm \mathrm{SD}$ ) were randomly assigned to one of 4 squares in a replicated $3 \times 3$ Latin square. Six of the cows were fitted with ruminal cannulae $(10 \mathrm{~cm}$ i.d.; Bar Diamond Inc., Parma, ID) $3 \mathrm{wk}$ before the start of the experiment. Average BW was $564 \pm 47 \mathrm{~kg}$ (mean \pm $\mathrm{SD})$ at the beginning of the experiment and $597 \pm 50$ $\mathrm{kg}$ at the end of the experiment. Experimental periods were $21 \mathrm{~d}$ in duration, with $14 \mathrm{~d}$ for treatment adaptation and $7 \mathrm{~d}$ for data collection. Treatments consisted of 3 isoenergetic and isonitrogenous diets containing increasing amounts of steam-rolled wheat: $0 \%$ of dietary DM (W0), $10 \%$ of dietary DM (W10), and $20 \%$ of dietary DM (W20). In W10 and W20, wheat was used as a direct replacement for steam-rolled barley. The diets were formulated for a $600-\mathrm{kg}$ cow producing 40 $\mathrm{kg}$ of milk/d containing 3.5\% fat and $3.2 \% \mathrm{CP}$ (NRC, 2001). Composition of the diets is shown in Table 1.

Cows were fed the diets as a TMR twice daily in equal portions at 1030 and $1630 \mathrm{~h}$ for ad libitum intake (10\% refusals). Moisture content of the silage was determined weekly and used to make ration adjustments. Feed ingredients and orts were sampled on d 14 and 20 of each period for determination of DM and subsequent nutrient analysis. Cows were housed in a tie-stall barn, given free access to water, and were turned outside on a dry-lot for 1 to $2 \mathrm{~h}$ daily after the morning milking, except on the day when rumen fluid samples were collected. Cows were milked twice daily at 0500 and 1600 h. Milk yield was recorded daily throughout the experiment, and milk was sampled on 2 consecutive days (d 19 and 20) during the a.m. and p.m. milkings during each period. The experimental protocol was approved by the Faculty Animal Policy and Welfare Committee of the University of Alberta and animals were cared for in accordance with the guidelines of the Canadian Council on Animal Care (1993).

\section{Rumen Fermentation and Whole-Tract Digestibility}

Ruminal fluid was sampled 18 times over a 24 -h period beginning on d 20. Samples were collected by a suction strainer as outlined by Khorasani and Kennelly (2001) from 5 locations in the rumen: anterior dorsal, anterior ventral, medial ventral, posterior dorsal, and posterior ventral. Forty milliliters of ruminal fluid was collected from each location. Sampling times were 1000, 1100, 1130, 1200, 1230, 1300, 1400, 1600, 1700, 1730, 1800, 1830, 1900, 2000, 2200, 2400, 0400, and $0800 \mathrm{~h}$. Ruminal fluid $\mathrm{pH}$ was determined immediately after collection using an Acumet XL15 pH meter (Fisher Scientific, Ottawa, Ontario, Canada). For the determination of VFA, $4 \mathrm{~mL}$ of ruminal fluid was acidified with $1 \mathrm{~mL}$ of $25 \%$ orthophosphoric acid ( $\mathrm{vol} / \mathrm{vol}$ ), while for the determination of lactate and $\mathrm{NH}_{3}-\mathrm{N}, 5 \mathrm{~mL}$ of rumen fluid were placed into aliquots. All samples were stored at $-20^{\circ} \mathrm{C}$ until analysis.

Chromic oxide was used as an indigestible marker for the determination of whole-tract nutrient digestibility using a modified method of Holden et al. (1994). Ten grams of chromic oxide was weighed onto filter paper, and the marker inserted directly into the rumen (pushed into the rumen mat) twice a day at 0815 and $1615 \mathrm{~h}$ from d 14 to d 21 of each period. Samples of feces were collected on 12 occasions from d 18 to 21 at 0800, 1600, 2400, 0600, 1400, 2200, 0400, 1200, 2000, 0200,1000 , and $1800 \mathrm{~h}$, such that an entire 24-h day was represented. Feces were collected by grab sampling or after voluntary defecation; $200 \mathrm{~g}$ of feces was collected from each cow on each occasion and composited. Samples were stored at $-20^{\circ} \mathrm{C}$ until dried at $55^{\circ} \mathrm{C}$, ground through a 1-mm screen, and analyzed for chromium and nutrient content.

\section{Chemical Analysis}

Milk fat, protein, and lactose were measured by infrared spectroscopy at the Central Milk Testing Laboratory (Edmonton, Alberta, Canada). Feed ingredients and feces were analyzed for $\mathrm{CP}(\mathrm{N} \times 6.25)$ using a Leco FP-428 Nitrogen Determinator (Leco Corp., St. Joseph, 
Table 1. Ingredient and nutrient composition of the experimental diets

\begin{tabular}{|c|c|c|c|}
\hline \multirow[b]{2}{*}{ Item } & \multicolumn{3}{|c|}{ Treatment $^{1}$} \\
\hline & W0 & W10 & W20 \\
\hline \multicolumn{4}{|l|}{ Ingredient composition, $\% \mathrm{DM}$} \\
\hline Alfalfa hay & 15.3 & 15.3 & 15.4 \\
\hline Barley silage & 34.9 & 34.9 & 35.1 \\
\hline Barley grain, steam-rolled & 29.6 & 19.5 & 9.5 \\
\hline Wheat grain, steam-rolled & - & 10.1 & 20.0 \\
\hline Corn grain, steam-rolled & 5.2 & 5.2 & 5.1 \\
\hline Canola meal & 2.0 & 2.0 & 2.0 \\
\hline Corn gluten meal & 5.7 & 5.7 & 5.6 \\
\hline Fish meal & 1.9 & 1.9 & 1.9 \\
\hline Canola oil & 1.5 & 1.5 & 1.5 \\
\hline Rumen bypass fat ${ }^{2}$ & 1.1 & 1.1 & 1.1 \\
\hline Molasses & 1.0 & 1.0 & 1.0 \\
\hline Sodium bicarbonate & 0.5 & 0.5 & 0.5 \\
\hline Limestone & 0.2 & 0.2 & 0.2 \\
\hline Dicalcium phosphate & 0.2 & 0.2 & 0.2 \\
\hline Magnesium oxide & 0.1 & 0.1 & 0.1 \\
\hline Mineral-vitamin premix ${ }^{3}$ & 0.7 & 0.7 & 0.7 \\
\hline Vitamin $\mathrm{E}^{4}$ & 0.1 & 0.1 & 0.1 \\
\hline \multicolumn{4}{|l|}{ Chemical composition, \% DM } \\
\hline DM & 43.3 & 43.3 & 43.2 \\
\hline $\mathrm{CP}$ & 17.5 & 17.1 & 17.1 \\
\hline NDF & 34.2 & 33.8 & 33.2 \\
\hline $\mathrm{ADF}$ & 22.6 & 22.5 & 22.2 \\
\hline Starch & 18.9 & 21.4 & 21.8 \\
\hline $\mathrm{NE}_{\mathrm{L}}$, Mcal $/ \mathrm{kg}^{5}$ & 1.60 & 1.60 & 1.61 \\
\hline
\end{tabular}

${ }^{1}$ Treatments: $0 \%$ (W0), 10\% (W10), and 20\% (W20) steam-rolled wheat added on a DM basis at the expense of steam-rolled barley grain.

${ }^{2}$ Megalac, Church \& Dwight Co. Inc., Princeton, NJ.

${ }^{3}$ Contained $0.1 \% \mathrm{Ca}, 0.6 \% \mathrm{P}, 0.3 \% \mathrm{Mg}, 11.5 \% \mathrm{Na}, 0.23 \% \mathrm{~S}, 6.2 \mathrm{mg}$ of $\mathrm{Co} / \mathrm{kg}, 1,170 \mathrm{mg}$ of Cu$/ \mathrm{kg}, 80 \mathrm{mg}$ of I/ $/ \mathrm{kg}$, $3,100 \mathrm{mg}$ of $\mathrm{Mn} / \mathrm{kg}, 40 \mathrm{mg}$ of Se/kg, 5,000 $\mathrm{mg}$ of $\mathrm{Zn} / \mathrm{kg}, 1,265,000 \mathrm{IU}$ of vitamin A/kg, 142,000 IU of vitamin $\mathrm{D} / \mathrm{kg}$, and $3,800 \mathrm{IU}$ of vitamin $\mathrm{E} / \mathrm{kg}$.

${ }^{4} 10,000 \mathrm{IU}$ of vitamin $\mathrm{E} / \mathrm{kg}$.

${ }^{5}$ Calculated from NRC (2001).

$\mathrm{MI}$ ), and for ADF and NDF using amylase and sodium sulfite on an Ankom 200 Fiber Analyzer (Ankom Technology, Macedon, NY) following the procedures of Van Soest et al. (1991). Fecal chromium content was determined by atomic absorption spectrophotometry (model 4000, Perkin Elmer, Waltham, MA) as described by Fenton and Fenton (1979), and nutrient digestibility estimated by using the $\mathrm{Cr}$ marker. Ruminal lactic acid and VFA were measured by gas chromatography as described by Khorasani et al. (1996), and ruminal $\mathrm{NH}_{3}-\mathrm{N}$ was measured enzymatically (Fawcett and Scott, 1960).

\section{Statistics}

Milk yield and composition data and DMI were reduced to a weekly mean before statistical analysis. Production and digestibility data were analyzed statistically according to a replicated Latin square design using the Mixed procedure of SAS (1999) with square, treatment, and period as the main effects, and cow(square) as the random effect. Rumen fermentation data were also analyzed using the Mixed procedure of SAS (1999) with time as the repeated measure using a model that included square, period, treatment, time, and the treatment $\times$ time interaction. The model was tested using cow(period) as the subject term and the $\mathrm{sp}$ (pow) covariance structure. Preplanned comparisons were used to evaluate the effects of wheat inclusion versus no wheat and 10\% wheat versus $20 \%$ wheat. Treatment differences were considered significant if $P$ $\leq 0.05$ and as a trend for $0.05<P \leq 0.10$. All data are reported as least squares means with pooled standard error of the means.

\section{RESULTS}

\section{Lactation Performance}

Dry matter intake was not different among the treatments, averaging $20.9 \pm 0.49 \mathrm{~kg} / \mathrm{d}$. Neither milk yield $(36.1 \pm 1.33 \mathrm{~kg} / \mathrm{d})$ nor milk component yields $(1.25$ $\pm 0.04,1.10 \pm 0.04$, and $1.67 \pm 0.07 \mathrm{~kg} / \mathrm{d}$ for fat, protein, and lactose, respectively) were affected by the 
DOEPEL ET AL.

Table 2. Dry matter intake and milk production of cows fed different amounts of wheat ${ }^{1}$

\begin{tabular}{|c|c|c|c|c|c|c|}
\hline \multirow[b]{2}{*}{ Variable } & \multicolumn{3}{|c|}{ Treatment $^{2}$} & \multirow[b]{2}{*}{ SEM } & \multicolumn{2}{|c|}{ Contrast, $P$-value ${ }^{3}$} \\
\hline & W0 & W10 & W20 & & B vs. W & W10 vs. W20 \\
\hline DMI, $\mathrm{kg} / \mathrm{d}$ & 21.4 & 20.5 & 20.8 & 0.49 & 0.15 & 0.51 \\
\hline \multicolumn{7}{|l|}{ Yield, kg/d } \\
\hline Milk & 35.9 & 36.0 & 36.4 & 1.33 & 0.78 & 0.75 \\
\hline Milk fat & 1.26 & 1.23 & 1.25 & 0.04 & 0.46 & 0.69 \\
\hline Milk protein & 1.11 & 1.07 & 1.11 & 0.04 & 0.67 & 0.33 \\
\hline Milk lactose & 1.65 & 1.67 & 1.69 & 0.07 & 0.56 & 0.69 \\
\hline \multicolumn{7}{|c|}{ Milk composition, $\%$} \\
\hline Fat & 3.52 & 3.44 & 3.43 & 0.10 & 0.32 & 0.96 \\
\hline Protein & 3.09 & 2.98 & 3.06 & 0.06 & 0.03 & 0.04 \\
\hline Lactose & 4.56 & 4.61 & 4.65 & 0.06 & 0.11 & 0.44 \\
\hline
\end{tabular}

${ }^{1}$ Data are presented as least squares means with pooled SEM, $\mathrm{n}=12$.

${ }^{2}$ Treatments: 0\% (W0), 10\% (W10), and 20\% (W20) steam-rolled wheat added on a DM basis at the expense of steam-rolled barley grain.

${ }^{3} P$-value for contrasts: $\mathrm{B}$ vs. $\mathrm{W}=$ main effect of wheat substitution (barley vs. wheat); W10 vs. W20 $=$ effect of $10 \%$ wheat versus $20 \%$ wheat.

proportional substitution of barley with wheat (Table $2)$. Treatment had no effect on milk fat or lactose percentage but milk protein content was lower (3.02 vs. $3.09 \% ; P=0.03$ ) for cows fed wheat than those fed only barley, and was higher for cows fed W20 than those fed W10 $(P=0.04)$.

\section{Ruminal Fermentation and Nutrient Digestibility}

Table 3 summarizes ruminal fermentation in response to wheat feeding. Ruminal $\mathrm{pH}$ (6.36 vs. $6.44 ; P=0.02$ ) was lower for cows fed wheat than for those not fed wheat, but there was no difference between cows fed $\mathrm{W} 10$ and W20 $(P=0.43)$. Concentrations of rumen $\mathrm{NH}_{3}-\mathrm{N}(11.5$ vs. $8.1 \mathrm{mg} / \mathrm{dL} ; P<0.01)$ and total VFA
(121 vs. $113 \mathrm{mM} ; P<0.0001$ ) were higher for cows fed wheat than for cows not fed wheat. Ruminal lactate tended to be higher for cows fed wheat than those fed only barley, but was not different between cows fed the 2 levels of wheat $(P=0.18)$. In contrast, the concentration of total VFA increased $(P<0.01)$ with W20 compared with W10. Rumen $\mathrm{pH}$ decreased after feeding (Figure 1) whereas concentrations of $\mathrm{NH}_{3}-\mathrm{N}$ (Figure 2) and lactate (Figure 3) increased one-half hour after feeding $(P<0.0001)$. There were no treatment by time interactions for any of the rumen parameters measured.

The ruminal concentration of propionate as a proportion of total VFA was lower for cows not fed wheat $(19.9$ $\mathrm{mol} / 100 \mathrm{~mol})$ than for those fed wheat $(20.7 \mathrm{~mol} / 100$

Table 3. Effect of dietary wheat on rumen fermentation characteristics in lactating dairy cows ${ }^{1}$

\begin{tabular}{|c|c|c|c|c|c|c|}
\hline \multirow[b]{2}{*}{ Variable } & \multicolumn{3}{|c|}{ Treatment $^{2}$} & \multirow[b]{2}{*}{ SEM } & \multicolumn{2}{|c|}{ Contrast, $P$-value ${ }^{3}$} \\
\hline & W0 & W10 & W20 & & B vs. W & W10 vs. W20 \\
\hline $\mathrm{pH}$ & 6.44 & 6.34 & 6.37 & 0.03 & 0.02 & 0.43 \\
\hline $\mathrm{NH}_{3}-\mathrm{N}, \mathrm{mg} / \mathrm{dL}$ & 8.10 & 12.86 & 10.12 & 0.94 & 0.01 & 0.01 \\
\hline Lactic acid, $\mathrm{m} M$ & 1.75 & 2.32 & 1.97 & 0.22 & 0.09 & 0.18 \\
\hline Total VFA, m $M$ & 113.1 & 116.1 & 125.7 & 3.04 & 0.01 & 0.01 \\
\hline \multicolumn{7}{|l|}{ VFA, mol/100 mol } \\
\hline Acetate & 66.0 & 65.2 & 65.4 & 0.85 & 0.26 & 0.70 \\
\hline Propionate & 19.9 & 20.5 & 20.9 & 0.68 & 0.01 & 0.17 \\
\hline Butyrate & 9.6 & 10.1 & 9.4 & 0.44 & 0.82 & 0.27 \\
\hline Isobutyrate & 0.89 & 0.84 & 0.83 & 0.06 & 0.35 & 0.95 \\
\hline Valerate & 1.43 & 1.34 & 1.34 & 0.05 & 0.11 & 0.95 \\
\hline Isovalerate & 1.55 & 1.52 & 1.55 & 0.09 & 0.90 & 0.81 \\
\hline Caproate & 0.61 & 0.57 & 0.54 & 0.03 & 0.14 & 0.51 \\
\hline $\mathrm{A}: \mathrm{P}$ ratio $^{4}$ & 3.36 & 3.24 & 3.17 & 0.13 & 0.01 & 0.21 \\
\hline
\end{tabular}

${ }^{1}$ Data are presented as least squares means with pooled SEM, $\mathrm{n}=6$.

${ }^{2}$ Treatments: $0 \%$ (W0), $10 \%$ (W10), and 20\% (W20) steam-rolled wheat added on a DM basis at the expense of steam-rolled barley grain.

${ }^{3} P$-value for contrasts: $\mathrm{B}$ vs. $\mathrm{W}=$ main effect of wheat substitution (barley vs. wheat); W10 vs. W20 = effect of $10 \%$ wheat versus $20 \%$ wheat.

${ }^{4}$ Acetate:propionate ratio. 


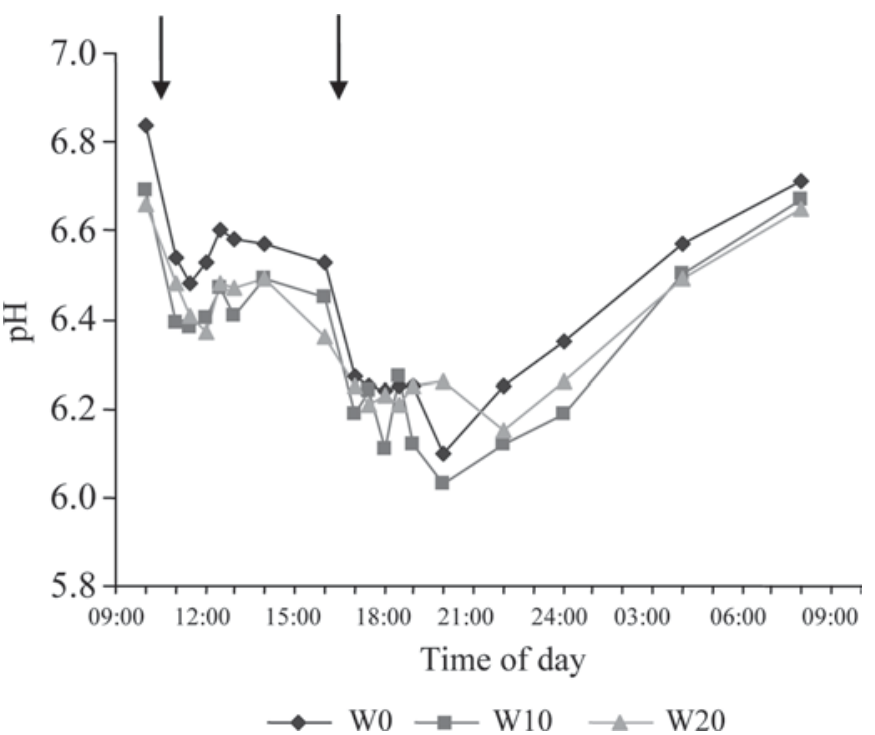

Figure 1. Diurnal patterns of rumen pH as influenced by dietary treatment: $0 \%$ wheat $(\bullet), 10 \%$ wheat $(\mathbf{\square})$, or $20 \%$ wheat $(\boldsymbol{\Delta})$. Rumen $\mathrm{pH}$ was determined on $\mathrm{d} 20$ and 21 of each period, $\mathrm{n}=6$. Arrows indicate the time of feeding. Probability of significance was $0.04,0.0001$, and 0.90 for treatment, time, and treatment by time interaction effects, respectively. Pooled standard error of the means was 0.07 .

mol; $P=0.01)$. Conversely, concentrations of acetate and butyrate were unaffected by the inclusion of wheat in the diet $(P>0.10)$. There were no differences between W10 and W20 for any of the individual VFA. Cows not fed wheat exhibited a higher acetate:propionate ratio than cows fed wheat (3.36 vs. $3.21 ; P<0.01$ ), but this ratio was not affected by increasing the level of wheat from $10 \%$ of dietary DM to $20 \%$.

Whole-tract nutrient digestibility is shown in Table 4 . There was no effect of treatment on any of the nutrients measured, with average digestibility being $72.4 \% \pm 4.4$ for $\mathrm{DM}, 73.6 \% \pm 5.9$ for $\mathrm{CP}, 63.8 \% \pm 5.5$ for $\mathrm{ADF}$, and $58.8 \% \pm 6.1$ for NDF.

\section{DISCUSSION}

\section{Lactation Performance}

The observation that DMI was not different among treatments is consistent with previously reported results. Faldet et al. (1989), who fed lactating dairy cows 0,21 , or $33 \%$ ground wheat as a percentage of dietary DM in place of ground corn, in conjunction with $45 \%$ sorghum silage, reported that DMI was not different among the 3 treatments. Similarly, cows fed a diet consisting of $60 \%$ hay and $38 \%$ pelleted wheat, corn, or barley had equivalent feed intakes (Tommervik and Waldern, 1969).

In the current study, milk yield was not different among the treatments, which can be attributed to the similarity among treatments for DMI and apparent whole-tract digestibility of the diets. McPherson and Waldern (1969) reported that increasing the level of wheat from $9 \%$ to $\sim 40 \%$ of total dietary DM (in place of barley) had no effect on milk yield. Those authors also reported that the inclusion of wheat in the diet did not result in a reduction in milk fat content, as was seen in the current study. Faldet et al. (1989) reported an increase in milk fat content when wheat was included at $33 \%$ of dietary DM but not when it was included at $22 \%$ of dietary DM, which is in agreement with the current study. Milk fat content did not decrease with dietary wheat inclusion, suggesting that dietary fiber intake was adequate (Krause and Oetzel, 2006) or that fiber degradation was not compromised (Kennelly et al., 1999). Additionally, the inclusion of sodium bicarbonate in the diet in the current study may have offset any potential for the dietary wheat to induce milk fat depression.

The decrease in milk protein content seen with the wheat treatments may be a reflection of the lower protein intake in these cows $(3,745 \mathrm{~g} / \mathrm{d}$ for barley-fed cows vs. $3,532 \mathrm{~g} / \mathrm{d}$ for wheat-fed cows). The numerically lower DM and CP digestibility associated with W10 may also be a contributing factor. In addition, the lower milk protein concentration may be related to the higher ruminal ammonia concentration, indicating lower utilization of dietary $\mathrm{N}$ with a resultant reduction in milk protein synthesis. Decreased $\mathrm{N}$ utilization could potentially result in a reduction in the microbial $\mathrm{N}$ pool

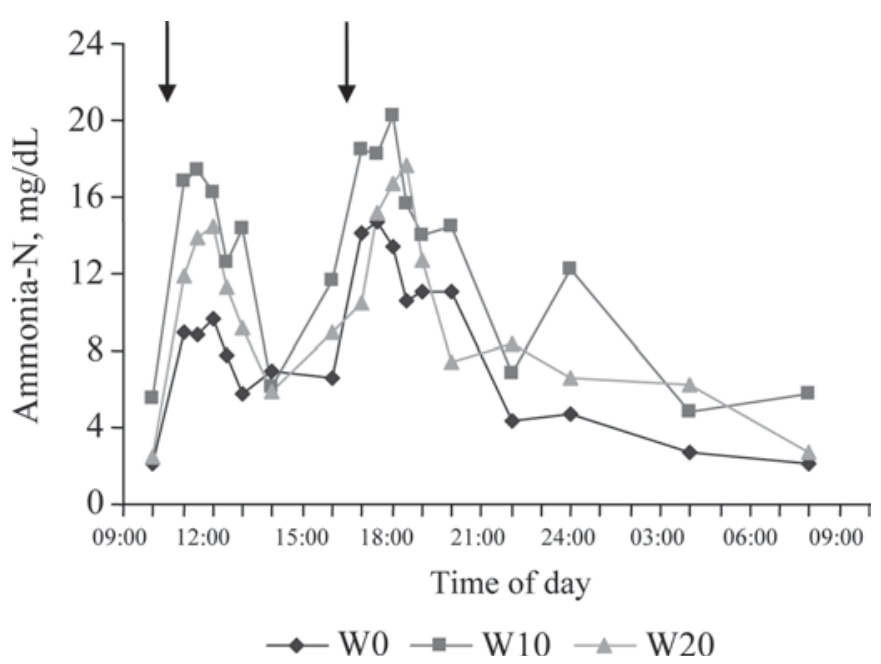

Figure 2. Diurnal patterns of rumen $\mathrm{NH}_{3}-\mathrm{N}$ as influenced by dietary treatment: $0 \%$ wheat $(\bullet), 10 \%$ wheat $(\mathbf{\square})$, or $20 \%$ wheat $(\mathbf{\Delta})$. Rumen ammonia concentrations were determined on d 20 and 21 of each period, $\mathrm{n}=6$. Arrows indicate the time of feeding. Probability of significance was $0.0001,0.0001$, and 0.46 for treatment, time, and treatment by time interaction effects, respectively. Pooled standard error of the means was 2.13 . 
with the wheat treatments. Gozho and Mutsvangwa (2008) reported that microbial $\mathrm{N}$ supply was lower in cows receiving a diet containing $30 \%$ wheat than in cows receiving a diet with $30 \%$ barley. In that study, total purine derivatives were also lower with the wheatbased diet.

\section{Ruminal Fermentation and Nutrient Digestibility}

The diurnal pattern of rumen $\mathrm{pH}$ with a prolonged depression following the afternoon feeding is similar to that reported by Rustomo et al. (2006) and is typical for grain-fed dairy cows (Keunen et al., 2002). Although rumen $\mathrm{pH}$ decreased when wheat replaced barley in the diet, $\mathrm{pH}$ remained in the normal physiological range for all 3 treatments. In fact, at no point in time (Figure 1) did $\mathrm{pH}$ fall to a level $(\mathrm{pH}<5.5)$ that would be indicative of subacute ruminal acidosis (Keunen et al., 2002). The small but biologically insignificant reduction in $\mathrm{pH}$ agrees with the data of Wadhwa et al. (2001). Using an in vitro assay, those authors determined that the acidproducing potential of barley and wheat was similar, with both grains being higher than corn. The increase in ruminal lactic acid concentration with wheat inclusion in the diet is in agreement with the decrease in rumen $\mathrm{pH}$. The lack of an effect on lactate concentration when W20 was fed versus W10 is also not surprising considering that lactate-producing bacteria proliferate when $\mathrm{pH}$ drops below 5.0 (Al Jassim et al., 2003; Stone, 2004).

The decline in $\mathrm{pH}$ with dietary wheat inclusion was associated with an increase in rumen VFA concentration. Such a correlation was also reported in the study of Shaw and Pryor (1972), in which there was a decrease in $\mathrm{pH}$ and a $28 \%$ increase in rumen VFA levels as the amount of wheat in the diet of steers increased from 15 to $85 \%$. One of the major concerns with grain feeding in dairy cows is optimization of ruminal $\mathrm{pH}$ and the ratio of acetate to propionate (Russell, 1998). Although there was a significant reduction in the acetate:propionate

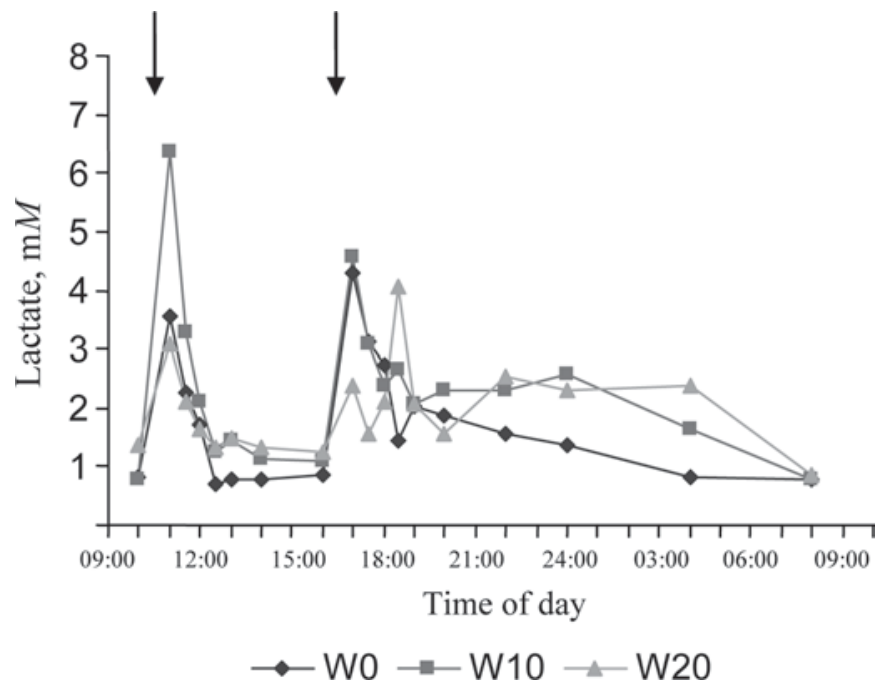

Figure 3. Diurnal patterns of rumen lactate as influenced by dietary treatment: $0 \%$ wheat $(\bullet), 10 \%$ wheat $(\mathbf{\square})$, or $20 \%$ wheat $(\boldsymbol{\Delta})$. Rumen lactate concentrations were determined on d 20 and 21 of each period, $\mathrm{n}=6$. Arrows indicate the time of feeding. Probability of significance was $0.09,0.0001$, and 0.67 for treatment, time, and treatment by time interaction effects, respectively. Pooled standard error of the means was 0.80

ratio with wheat feeding, which reflects greater starch fermentation of wheat compared with barley, it did not result in a reduction in milk fat concentration.

The higher concentration of total VFA with W20 versus W10 reflects a greater efficiency of starch fermentation with the increased wheat level (De Campeneere et al., 2006). However, the absence of a drop in $\mathrm{pH}$ with the higher VFA concentration is somewhat unexpected considering the normal association between $\mathrm{pH}$ and VFA levels. However, lactic acid concentration was numerically lower with W20 than W10 and considering that lactic acid is more acidogenic than VFA this may partially explain why rumen $\mathrm{pH}$ was not lower with W20 than W10.

The increase in ruminal $\mathrm{NH}_{3}-\mathrm{N}$ concentrations with wheat feeding suggests that protein degradation with

Table 4. Whole-tract apparent digestibility of nutrients in lactating dairy cows fed different amounts of wheat $^{1}$

\begin{tabular}{|c|c|c|c|c|c|c|}
\hline \multirow[b]{2}{*}{ Digestibility, \% } & \multicolumn{3}{|c|}{ Treatment $^{2}$} & \multirow[b]{2}{*}{ SEM } & \multicolumn{2}{|c|}{ Contrast, $P$-value ${ }^{3}$} \\
\hline & W0 & W10 & W20 & & B vs. W & W10 vs. W20 \\
\hline $\mathrm{DM}$ & 72.8 & 68.5 & 75.9 & 4.4 & 0.90 & 0.20 \\
\hline $\mathrm{CP}$ & 75.0 & 68.5 & 77.2 & 5.9 & 0.69 & 0.19 \\
\hline $\mathrm{ADF}$ & 64.6 & 58.8 & 67.9 & 5.5 & 0.84 & 0.23 \\
\hline NDF & 60.1 & 52.8 & 63.4 & 6.1 & 0.78 & 0.21 \\
\hline
\end{tabular}

${ }^{1}$ Data are presented as least squares means with pooled SEM, $\mathrm{n}=6$.

${ }^{2}$ Treatments: $0 \%$ (W0), 10\% (W10), and 20\% (W20) steam-rolled wheat added on a DM basis at the expense of steam-rolled barley grain.

${ }^{3} P$-value for contrasts: $\mathrm{B}$ vs. $\mathrm{W}=$ main effect of wheat substitution (barley vs. wheat); W10 vs. W20 = effect of $10 \%$ wheat versus $20 \%$ wheat. 
the wheat diets exceeded carbohydrate availability. Rapid degradation may compromise synchronization of carbon skeletons with $\mathrm{N}$ released from forage degradation. One of the indicators of the nutritive value of cereal grains is the synchrony index, which is a measure of the synchrony of degradable $\mathrm{N}$ and energy supply in the rumen, with 1 being perfect synchrony (Sinclair et al., 1993). It is possible that the synchrony index was lower with the wheat diets than the barley diet resulting in a reduction of microbial capture of $\mathrm{N}$ and a concomitant accumulation of ruminal ammonia.

In the current study, whole-tract apparent digestibility was not different among treatments; however, for all parameters measured, digestibility of W10 was numerically lower than the other 2 treatments. This was unexpected and is difficult to explain biologically, considering that W10 is intermediate in wheat content between W0 and W20. It is possible that there was incomplete and inconsistent recovery of the marker, which would result in falsely elevated digestibility values. Relative to other published values, the current digestibility coefficients appear high. For example, Yang et al. (2000), using diets similar to the ones used in the current study, reported NDF and ADF digestibility of $56 \%$ and $44 \%$, respectively. Similarly, Gozho and Mutsvangwa (2008) reported average NDF digestibility of $38 \%$ on diets containing approximately $30 \%$ dry-rolled barley, oats, wheat, or corn. It is interesting to note that in that study the $30 \%$ NDF digestibility of the wheat diet was not significantly different than the $41 \%$ NDF digestibility of the barley diet.

\section{CONCLUSIONS}

Feeding steam-rolled wheat to dairy cows at $20 \%$ of dietary DM did not compromise DMI or yields of milk and milk components. Despite a statistically significant decline in rumen $\mathrm{pH}$ with the wheat treatments, $\mathrm{pH}$ was still maintained within a desirable range, above that needed to induce subacute ruminal acidosis. Whole-tract digestibilities of DM, CP, ADF, and NDF were unaffected by treatment. In conclusion, under the conditions in this study, steam-rolled wheat grain was used as a replacement for steam-rolled barley grain at up to $20 \%$ of dietary DM without causing detrimental effects on animal productivity.

\section{REFERENCES}

Al Jassim, R. A. M., G. L. R. Gordon, and J. B. Rowe. 2003. The effect of basal diet on lactate producing bacteria and the susceptibility of sheep to lactic acidosis. Anim. Sci. 77:459-469.

Canadian Council on Animal Care. 1993. Guide to the Care and Use of Experimental Animals. Vol. 1, 2nd ed. E. D. Olfert, B. M. Cross, and A. A. McWilliam, ed. CCAC, Ottawa, Ontario, Canada.
De Campeneere, S., J. L. De Boever, and D. L. De Brabander. 2006. Comparison of rolled, $\mathrm{NaOH}$ treated and ensiled wheat grain in dairy cattle diets. Livest. Sci. 99:267-276.

Faldet, M. A., T. Nalsen, L. J. Bush, and G. D. Adams. 1989. Utilization of wheat in complete rations for lactating cows. J. Dairy Sci. 72:1243-1251.

Fawcett, J. K., and J. E. Scott. 1960. Determination of ammonia nitrogen. J. Clin. Pathol. 13:156-159.

Fenton, T. W., and M. Fenton. 1979. An improved method for the determination of chromic oxide in feed and feces. Can. J. Anim. Sci. 59:631-634.

Gozho, G. N., and T. Mutsvangwa. 2008. Influence of carbohydrate source on ruminal fermentation characteristics, performance, and microbial protein synthesis in dairy cows. J. Dairy Sci. 91:27262735 .

Herrera-Saldana, R. E., J. T. Huber, and M. H. Poore. 1990. Dry matter, crude protein, and starch degradability of five cereal grains. J. Dairy Sci. 73:2386-2393.

Holden, L. A., L. D. Muller, G. A. Varga, and P. J. Hillard. 1994. Ruminal digestion and duodenal nutrient flows in dairy cows consuming grass as pasture, hay, or silage. J. Dairy Sci. 77:30343042 .

Huntington, G. B. 1997. Starch utilization by ruminants: From basics to the bunk. J. Anim. Sci. 75:852-867.

Kennelly, J. J., B. Robinson, and G. R. Khorasani. 1999. Influence of carbohydrate source and buffer on rumen fermentation characteristics, milk yield, and composition in early-lactation Holstein cows. J. Dairy Sci. 82:2486-2496.

Keunen, J. E., J. C. Plaizier, L. Kyriazakis, T. F. Duffield, T. M. Widowski, M. I. Lindinger, and B. W. McBride. 2002. Effects of a subacute ruminal acidosis model on the diet selection of dairy cows. J. Dairy Sci. 85:3304-3313.

Khorasani, G. R., and J. J. Kennelly. 2001. Influence of carbohydrate source and buffer on rumen fermentation characteristics, milk yield, and milk composition in late-lactation Holstein cows. J. Dairy Sci. 84:1707-1716.

Khorasani, G. R., E. K. Okine, and J. J. Kennelly. 1996. Forage source alters nutrient supply to the intestine without influencing milk yield. J. Dairy Sci. 79:862-872.

Krause, K. M., and G. R. Oetzel. 2006. Understanding and preventing subacute ruminal acidosis in dairy herds: A review. Anim. Feed Sci. Technol. 126:215-236.

McPherson, R. G., and D. E. Waldern. 1969. Pacific northwest soft white wheat for lactating cows. J. Dairy Sci. 52:84-89.

National Research Council. 2001. Nutritional Requirements of Dairy Cattle. 7th rev. ed. Natl. Acad. Sci., Washington, DC.

Offner, A., A. Bach, and D. Sauvant. 2003. Quantitative review of in situ starch degradation in the rumen. Anim. Feed Sci. Technol. 106:81-93.

Russell, J. B. 1998. The importance of $\mathrm{pH}$ in the regulation of ruminal acetate to propionate ratio and methane production in vitro. J. Dairy Sci. 81:3222-3230.

Rustomo, B., O. AlZahal, N. E. Odongo, T. F. Duffield, and B. W. McBride. 2006. Effects of rumen acid load from feed and forage particle size on ruminal $\mathrm{pH}$ and dry matter intake in the lactating dairy cow. J. Dairy Sci. 89:4758-4768.

SAS Institute. 1999. SAS User's Guide. Statistics, Version 8 ed. SAS Inst. Inc., Cary, NC.

Shaw, F. D., and W. J. Pryor. 1972. Feeding wheat to cattle. 2. The effect of level of wheat and sodium bicarbonate on ruminal characteristics. Aust. Vet. J. 48:504-507.

Sinclair, L. A., P. C. Garnsworthy, J. R. Newbold, and P. J. Buttery. 1993. Effect of synchronising the rate of dietary energy and nitrogen release on the rumen fermentation and microbial protein synthesis in sheep. J. Agric. Sci. 120:251-263.

Stone, W. C. 2004. Nutritional approaches to minimize subacute ruminal acidosis and laminitis in dairy cattle. J. Dairy Sci. 87(E Suppl.):E13-E26.

Tománková, O., and P. Homolka. 2004. In vitro ruminal degradability of cereal grain starch. Czech J. Anim. Sci. 49:151-155. 
Tommervik, R. S., and D. E. Waldern. 1969. Comparative feeding value of wheat, corn, barley, milo, oats, and a mixed concentrate ration for lactating cows. J. Dairy Sci. 52:68-73.

Turgut, L., M. Macit, and M. Karaoğlu. 2004. Crude protein degradation of some energy feeds measured by nylon bag technique. J. Appl. Anim. Sci. 25:81-84.

Van Soest, P. J., J. B. Robertson, and B. A. Lewis. 1991. Methods for dietary fiber, neutral detergent fiber and non-starch polysaccharide in relation to animal nutrition. J. Dairy Sci. 74:3583-3597.
Wadhwa, D. W., N. F. G. Beck, L. P. Borgida, M. S. Dhanoa, and R. J. Dewhurst. 2001. Development of a simple in vitro assay for estimating net rumen acid load from diet ingredients. J. Dairy Sci. 84:1109-1117.

Yang, W. Z., K. A. Beauchemin, and L. M. Rode. 2000. Effects of barley grain processing on extent of digestion and milk production of lactating cows. J. Dairy Sci. 83:554-568. 